\title{
NON-REFOULMENT AND AGE ASSESSMENT OF MINORS
}

Kamila Danilovna Shaibakova

Kazan Federal University, Kazan, Russia.

Adel Ilsiyarovich Abdullin

Kazan Federal University, Kazan, Russia.

E-mail: kamila.shaibakova@gmail.com

Recepción: 05/08/2019 Aceptación: 09/09/2019 Publicación: 23/10/2019

\section{Gitación sugerida:}

Shaibakova, K.D. y Abdullin, A.I. (2019). Non-refoulment and age assessment of minors. 3C TIC. Cuadernos de desarrollo aplicados a las TIC. Edición Especial, Octubre 2019, 44-57. doi: https://doi.org/10.17993/3ctic.2019.83-2.44-57

Suggested citation:

Shaibakova, K.D. \& Abdullin, A.I. (2019). Non-refoulment and age assessment of minors. 3C TIC. Cuadernos de desarrollo aplicados a las TIC. Special Issue, October 2019, 4457. doi: https://doi.org/10.17993/3ctic.2019.83-2.44-57 


\section{ABSTRACT}

Situations when legal framework overlaps with the other areas sometimes rise the important questions. The age assessment is one of those areas where medical age determination directly affects human rights. A public entity uses a person's age to determine the age of a person in the absence of legal evidence. Medical age assessment applies more frequently in the asylum cases when unaccompanied minors arrive in a country where he/she seeks asylum. It is claimed that minors might not be fully honest concerning their age as being minor ease the application process. This is one of the reasons why medical assessment is required. However, often the assessment is not correct, and minors are declared of the full legal age. In addition, ways the medical assessment is carries could violate the rights per se. Therefore, often minors being surrendered or deported to the countries where the risks exist in reversal of the principle of no refund.

\section{KEYWORDS}

Age assessment, Non-refoulment, Refugee, Asylum, Minor, Children, Human rights. 


\section{INTRODUCTION}

The asylum-seeking process often became a tool for abuses. Immigration officers and social workers frequently challenge the age and reasons for asylum, claiming that information might not be truthful. When children come to the territory of a host state unaccompanied and without valid identification papers, the need of age assessment often arises. However, often the assessment is not correct, and minors are declared of the full legal age. Therefore, often minors being surrendered or deported to the countries where the risks exist in reversal of the essence of non-refund. However, age determination is flawed on the system. The medical procedures often dangerous for the health of a child and cannot produce any credible results. The interviews and conversation with social workers cannot give a definite answer just as in no personal circumstance they are not considered ethnic and cultural characteristics. Therefore, the system requires changes and improvements.

\section{METHODS}

The research question that is important to answer is does age assessment of minors violates certain human rights? The research question is of a descriptive and normative character. It is important to identify the type of the research question in order to choose the most appropriate research design. The first part of the research question is a descriptive as it examines how the law is (or lex lata). The article is looking at the existing law and jurisprudence of national, regional and international judicial bodies. The case study helps to explain both the process and consequences of a legal phenomenon via complete observation and analysis of the cases at stake. The European countries use the age assessment extensively; therefore, the example of the EU relevant to the article. In order to conduct a proper literature review, it is highly important to understand what the role of the literature is. Due to the type of the research question and the traditional legal nature of the research, academic literature is of a paramount importance. The 
research question could technically be answered based on the analysis of the case-law alone, however, the academic literature provides relevant background information and introduces the existent perspectives on the issue.

\section{RESULTS AND DISCUSSION}

Legal framework. The medical assessment is important in order to give an opportunity to enjoy a wide range of rights. The appropriate protection regime applies to asylum-seeker children, who are provided with residence, education, health care and supportive legal provisions to prohibit child detention, although they do not belong to persons over the age of eighteen; Adults should be arrested and made homeless. (Feltz, 2015; Kheirabadi \& Mirzaei, 2019).

The rights of the Convention on Refugees, undocumented children and lonely children are taken away from their families. (hereinafter - RC). Refugee extradition to countries where his life and liberty are threatened on grounds of nationality, race, religion, membership of a particular social group or group of differing political views, is regulated in Article $31 \mathrm{RC}$ with the content of the refugee return ban. Art. 22 RG prohibits general discrimination. Children with or without guardians seeking asylum may enjoy the protection and humanitarian assistance provided for in Article 5 of the Convention on the Rights of the Child. In addition, the best interests of refugee children and their assessment of their age should be considered in all childcare activities.

Ensuring that the child is properly identified for the rights mentioned above is very important. So when refugee children are identified for countries, they should be immediately identified and separated (Costello \& Hancox, 2015; Kashisaz \& Mobaraki, 2018). The identification measures may include an age assessment (Roscam Abbing, 2011; Kutuev et al., 2017). For example, a grandfather and his child apply for international convention support, according to the mental state, age and puberty the child must research if is a margin of interpretation, must be given the benefit of the doubt, the person who claims to be a minor. 
In order to assess age, different medical approaches have been taken in different countries. Medical tests that include measurements of puberty or radiological growth are most commonly used, the medial ends of both collarbones.

\section{Approaches}

Compared to the GRULAC and Pyle Atlas or the Tanner and Whitehouse pictures in order to determine the bone age of the child, Wrist X-rays are taken which is the most widely used medical methods.

$\mathrm{X}$-rays are taken in different ways in different countries; the Netherlands, X-rays of the spoke bone, in France, $\mathrm{x}$-rays of the left hand and wrist are taken and in Belgium, $\mathrm{x}$-ray of the entire dentistry, and $\mathrm{x}$-rays of the left wrist and collarbone which is fames a so-called triple test.

In Sweden, the National Board of Forensic Medicine has the task of carrying out the medical age assessments consisting of X-ray examinations of the knee joint and wisdom tooth. In practice, it is the dentist and doctor of the contracted healthcare provider who makes the assessment. In addition, interviews are also used in order to assess age.

\section{A problem}

Firstly, an age assessment has been widely criticized by the human rights lawyers as being unreliable and providing false results that could deprive a minor of international protection. For example, wrist x-ray indices based on the Caucasian American or British middle-class population are stated in the report by the French National Advisory Ethics Committee. It raises risks for children from other areas in the world.

Secondly, different countries take different approaches regarding the age determination; thus, while in one country a refugee can be declared a minor, in another country it might not be a case. Thirdly, the issue of free will; If every asylum seeker refuses to undergo a medical examination, they will be treated as an adult. Therefore, required informed consent to conduct an assessment 
cannot be given based on a free will of a person. This, of course, has drawn sharp criticism from the UNHCR, it is held that refusing medical examinations cannot prevent international protection for asylum children. (Separated Children in Europe Program, 2012).

Fourthly, most specialist doctors say that age estimation is an estimation and it is very difficult for those between the ages of 5 and 6 , while in other places it is very important. In fact, the medical methods can only estimate age, and this will make us fall into the margin of error. No reliable method for pediatricians at Royal College of England has been able to provide accurate age detection. They believe that there are several factors that influence the maturation and the process of skeletal maturation.

Assessment of age should be provided only with other available evidence that can be validated by the English Supreme Court if medical tests have failed to provide definitive proof of age and their most accurate measurement shows at least two years of error. Thus, the role of interviews conducted by social workers became an important step. While being a compromise, the interviews with social workers have been heavily criticized by various NGOs as being subjective interpretations.

An important case in this regard is the Case of Mubilanzila Mayeka and Kaniki Mitunga v. Belgium (Mayeka, 2006), considered by the ECH Rights. The wrong treatment of a child might constitute a reversal of Art. 3, the prohibition of torture and other graft. In that case, the 4-year-old girl, arrived in Belgium as a refugee child who is not a neighbor, he was detained along with other adults who caused him depression. Finally, the court concluded that this orphaned child, who is an illegal immigrant in a foreign country and is not supported by the family, will certainly be vulnerable. Secondly, the child was sent to the Republic of the Congo without any supervision of the child there (Mayeka, 2006; Qazvini, 2018; Eslami \& Ahmadi, 2019; Jabbari et al., 2019).

The interview assessment being called a good alternative for age determination raises new problems and challenges to human rights. Firstly, the social workers and personnel are not sufficiently trained to assess the age. Secondly, children 
who have been subjected to traumatic experiences, if you want to grow quickly to survive and do what they have been able to do. Subjective assessment can also be a case when the age assessed by a person, even if sufficiently trained. Thus, the language a child speaks sometimes affect the age assessment. Heaven Crawley gives examples of children who spoke English to the immigration officer or social workers, so it was decided that they are over 18 years old as they could speak good English (Feltz, 2015; Nakhaee \& Nasrabadi, 2019).

Undoubtedly, the medical age assessment can violate the human dignity of a person, however, it could directly affect the life of a minor as when declared an adult, a person denied the asylum and shall leave the country and be back to the home state where the high risks exist (Crawley, 2007). One of the recent cases was brought to attention in Sweden. In 2015, a boy applied for asylum. He conducted an age survey at the request of the immigration board, where the growth of his wisdom teeth and knee joint was examined. The Swedish National Board of Forensic Medicine concludes that he is 18 or older and his application for asylum was rejected. This case again showed that the margin of error is extremely high. It has been stated that one-third of all children assessed by the Swedish National Forensic Medicine in 2017 were incorrectly classified as adults. Secondly, often there is a contradiction between different types of medical assessments. In the case, the examination of the boy's knee joint showed that he was probably over the age of 18 while the assessment of the wisdom teeth supported him as a minor.

This case also shows that the medical assessment and the asylum decision can take years. And while being a minor while applying for asylum, a person could become an adult when the decision will

finally be made. This affects the law to demand and the right to therapy. Unaccompanied minors are particularly vulnerable: coming to a new country without family, speaking a different language, expertise and assessment of the social services. Therefore, judicial review should always be available and a possibility for appeal shall be explained. 
Vivien Felts' has shown a significant and credible result because age measurement is not recognized as harassment or torture, although the European Court of Human Rights has not yet filed a complaint about how to identify age. Notwithstanding all these interpretations, the examination of the asylum seeker's age can violate Article 8 of the European Convention on Human Rights. For countries that consider systematically evaluating age as the only option, and systematic formulation, it is likely that this device is not appropriate because of the high margin of error of the process and the importance of its consequences for the lives of these children. The absence of other remedies and revisions to the above will undermine the rights of refugee children in art 13 ECHR.

The Parliamentary Assembly of the CE brought attention to the potential risks when it comes to age determination: when there is a reasonable doubt, an independent authority shall make a second opinion, Methods consistent with ethical indicators in medicine that: It's less frequent shall be used and the presumption of the minority shall be guaranteed (UNHCR, 2014). The PACE highlighted that child protection shall be prioritized rather than immigration control.

There are still undocumented asylum seekers who are often neglected by governments during various forms of migration.

\section{SUMMARY}

Thus, this is a structural problem that in recent years has hit unaccompanied young people seeking asylum in Europe. Most of the decisions have been made based on unreliable data. International protection has thus in practice become inaccessible to many people from one of the most vulnerable groups globally, in reversal of both the EC and the treaty on the laws of the kid. In accordance with the international and the local legal framework, a child is entitled to protection. The incorrect age determination puts a principle of the best interest of a child 
at risk. It is better to pay more attention to raising the level of protection for the rights of refugee children when assessing their age from their circumstances, as well as issues such as their ethnic and cultural background.

\section{CONCLUSION}

The article demonstrated that the current state of the age assessment process needs to be changed and improved. Trying to make an asylum-seeking process more effective, the best interest of a child often neglected. The humiliating procedures violate human dignity, right to privacy. The hindrances to appeal the decision of refusing the asylum or deportation could violate the law to an impressive therapy besides justice. The ethical besides cultural specifications of a child rarely have been considered in addition to the application of the medical assessments that were created for American "Caucasian" population or for a British middleclass population. Unaccompanied minors are particularly vulnerable: coming to a new country without family, speaking a different language, expertise, often they do not know how to react and with these bring suspicions to the social and immigration services. Unfortunately, there are many cases when minors were denied asylum based on the wrong or superficial age assessment. They are sent back to the countries where considerable risks exist, therefore the principle of non-refoulment is also at stake.

\section{ACKNOWLEDGEMENTS}

The work is performed according to the Russian Government Program of Competitive Growth of Kazan Federal University. 


\section{REFERENCES}

Costello, C., \& Hancox, E. (2015). The Recast Asylum Procedures Directive 2013/32/EU: Caught between the Stereotypes of the Abusive Asylum Seeker and the Vulnerable Refugee. Forthcoming in V. Chetail, P. De Bruycker \& F. Maiani (eds) Reforming the Common European Asylum System: The New European Refugee Law (Martinus Nijhoff, 2015); Oxford Legal Studies Research Paper No. 33/2015. Retrieved from https://papers.ssrn.com/sol3/papers. cfm?abstract_id=2609897

Crawley, H. (2007). When is a Child not a Child? Asylum, Age Disputes and the Process of Age Assessment. London: Immigration Law Practitioners' Association (ILPA). Retrieved from https://pureportal.coventry.ac.uk/en/ publications / when-is-a-child-not-a-child-asylum-age-disputes-and-theprocess-o

Eslami, R., \& Ahmadi, S. (2019). Investigating the Role of Educational Media on Secondary School Students' Learning Process Improvement in Jahrom City. Journal of Humanities Insights, 03(01), 13-16. doi: https://doi.org/10.22034/ jhi.2019.80890

Feltz, V. (2015). Age assessment for unaccompanied minors. MdM International Network Head Office. Nantes, France. Retrieved from https://mdmeuroblog.files. wordpress.com/2014/01/age-determination-def.pdf

Jabbari, E., Charbaghi, Z., \& Dana, A. (2019). Investigating the Effects of Educational and Motivational Education at Different Levels on the Performance and Application of dart throwing. Fournal of Humanities Insights, 03(02), 37-44. doi: https://doi.org/10.22034/jhi.2019.80896

Kashisaz, S., \& Mobaraki, E. (2018). The Effects of Private Education Institutes in Providing Modern Financial Knowledge in Developing Countries. Fournal of Humanities Insights, 02(04), 172-178. doi: https://doi.org/10.22034/ jhi.2018.80887 
Kheirabadi, M. A., \& Mirzaei, Z. (2019). Descriptive valuation pattern in education and training system: a mixed study. Fournal of Humanities Insights, 03(01), 7-12. doi: https://doi.org/10.22034/jhi.2019.80889

Kutuev, R. A., Mashkin, N. A., Yevgrafova, O. G., Morozov, A. V., Zakharova, A. N., \& Parkhaev, V. T. (2017). Practical Recommendations on the Organization of Pedagogical Monitoring in Institutions of Vocational Education. International Electronic Fournal of Mathematics Education, 12(1), 3-13. Retrieved from https://www.iejme.com/article/practical-recommendationson-the-organization-of-pedagogical-monitoring-in-institutions-of

Mayeka, M. (2006). Kaniki Mitunga v. Belgium. Retrieved from https:/ /hudoc. echr.coe.int/FRE\#\{\%22itemid\%22:[\%22001-77447\%22]\}

Nakhaee, J., \& Nasrabadi, M. A. (2019). Strategies for Research-Centered Education of Architectural Designing by Examining the Research-Centered Activities of the Top Universities. Fournal of Humanities Insights, 3(2), 50-56. Retrieved from http://www.jhumanities.net/article_80898_dcaa625489b5f0 ff63aea1583a374ee8.pdf

Parliamentary Assembly | Assemblée Parlementaire. (2011). Unaccompanied children in Europe: issues of arrival, stay and return. Resolution 1810. Retrieved from http://assembly.coe.int/nw/xml/XRef/Xref-XML2HTMLen.asp?fileid $=17991$

Qazvini, F. (2018). Investigating the Relationship between Mental Health and Social Adjustment (Case Study: Ayatollah Rouhani Hospital in Babol). UCT Fournal of Social Sciences and Humanities Research, 6(2), 1-5. Retrieved from http:/ / www.uctjournals.com/archive/ujsshr/2018/June/1.pdf

Roscam Abbing, H. D. C. (2011). Age determination of unaccompanied asylum seeking minors in the European Union: a health law perspective. European journal of health law, 18(1), 11-25. doi: https://doi.org/10.1163/157180911X546101 
Separated Ghildren in Europe Programme. (2012). Position Paper on Age Assessment in the Context of Separated Children in Europe, 8. Retrieved from http:// www.refworld.org/docid/4ff535f52.html

UN High Commissioner for Refugees (UNHCR). (2014). Safe E Sound: what States can do to ensure respect for the best interests of unaccompanied and separated children in Europe. Retrieved from https://www.refworld.org/docid/5423da264.html

Zhampeisov, K., Balykbayev, T., Kolumbayeva, N. K. S., \& Aitpayeva, A. (2018). National Component of the Training Content of the Teachers in Kazakhstan's school. Opción, 34(85-2), 653-677. 
Edición Especial Special Issue Octubre 2019 DOI: https://doi.org/10.17993/3ctic.2019.83-2.44-57 